\title{
The Validity of the Assessment and Treatment of Radicalization Scale: A Psychometric Instrument for Measuring Severity of Extremist Muslim Beliefs
}

Yusef Karimi

Independent Consultant, yukarimi@yahoo.com

Adarsh Kholi

Department of Psychiatry, Postgraduate Institute of Medical Education \& Research (PGIMER), Chandigarh, India., adarsh@hotmail.com

Ann-Mari Hesselink

University of South Africa, Pretoria, hesselae@unisa.ac.za

Johan Prinsloo

prinsjh@unisa.ac.za

Stella Bhawanie

Follow this and additional works at: https://digitalcommons.usf.edu/jss

pp. 28-44

See next page for additional authors

\section{Recommended Citation}

Karimi, Yusef; Kholi, Adarsh; Hesselink, Ann-Mari; Prinsloo, Johan;

Bhawanie, Stella; Andreu, José M; Ahmed, Adekunle G.; Loza, Wagdy; and Cimbura, Alexandra. "The Validity of the Assessment and Treatment of Radicalization Scale: A Psychometric Instrument for Measuring Severity of Extremist Muslim Beliefs." Journal of Strategic Security 14, no. 3 (2021) : 28-44.

DOI: https://doi.org/10.5038/1944-0472.14.3.1934

Available at: https://digitalcommons.usf.edu/jss/vol14/iss3/2

This Article is brought to you for free and open access by the Open Access Journals at Digital Commons @ University of South Florida. It has been accepted for inclusion in Journal of Strategic Security by an authorized editor of Digital Commons @ University of South Florida. For more information, please contact digitalcommons@usf.edu. 


\title{
The Validity of the Assessment and Treatment of Radicalization Scale: A Psychometric Instrument for Measuring Severity of Extremist Muslim Beliefs
}

\author{
Abstract \\ The Assessment and Treatment of Radicalization Scale (ATRS) is designed to quantitatively \\ measure Muslim extremists' ideologies regarding risk areas that are reported in the \\ literature. Utilizing the scale, in this study, using a convenience sample of 1769 from 10 \\ countries (Australia, Canada, Egypt, India, Iran, Iraq, Nigeria, Pakistan, Spain, and South \\ Africa) responded to the ATRS. Results supported previous findings about the reliability \\ and validity of the Assessment and Treatment of Radicalization Scale (ATRS, formerly \\ known as Belief Diversity Scale BDS, Loza, 2007) for assessing Muslim extremists. \\ Suggested cut off scores to use for identifying possible extremists are provided.
}

Acknowledgements

The authors wish to express their appreciation to the participants who were involved in this study.

Authors

Yusef Karimi, Adarsh Kholi, Ann-Mari Hesselink, Johan Prinsloo, Stella Bhawanie, José M Andreu, Adekunle G. Ahmed, Wagdy Loza, and Alexandra Cimbura 


\section{Introduction}

Research on fundamentalism, especially the new wave of Muslim Jihadists, has been a growing field in social sciences. Researchers ascribe this growth to the devastating terror attacks in recent years, threatening stability worldwide. ${ }^{1}$ One of the fundamental aspects of conducting empirical research is to the development of an adequate and validated measurement tool, with capabilities of capturing the phenomenon in question. Thus, this research investigates the reliability and validity of the Assessment and Treatment of Radicalization Scale (ATRS) to measure Muslim Jihadist ideologies and the prevalence of Muslim extremists' ideologies in different parts of the world. Validating tools for assessment of Muslim extremist can be beneficial in the field of criminal justice.

Extremist and terrorist acts frequently cause more damage and causalities than an act committed by a violent offender. In this regard, since 9/11, Islamic terrorists have committed more than 36,634 fatal terror attacks. ${ }^{2}$ The Jihad Report, on TheReligionofPeace.Com website, highlighted that 30 Islamic terror attacks in nine countries from March 28, 2020 to April 3, 2020, with 103 fatalities, 76 injured persons and one suicide blast. 3 Despite its prominence, not much attention has been given to the development of actuarial tools specifically designed to assess Muslim extremists' extremism and terrorism. As a result, When Psychiatrists and Psychologists complete assessments of a Muslim extremist, they utilize clinical and actuarial assessment tools designed for predicting violence such as the Psychopathy Checklist-Revised (PCL-R), The Violence Risk Appraisal Guide (VRAG), and the Level of Service/Case Management Inventory (LS/CMI), or rely on their professional judgment or use a structured professional judgment (SPJ) style.

The field of predicting offenders' risk for violent and non-violent recidivism went through four stages. The first generation that emerged in the 1920 s involved professionals making clinical judgments on the offender's risk to the community and treatment needs. Mental health professionals recognize that clinical judgment alone is often an intuitive and inaccurate risk predictor. As such, the potential to be subjective contributed to the unpopularity of clinical judgment alone in the 1970s. 4 The second generation, known as regression modeling, encompassed a more objective prediction by utilizing actuarial risk assessments that 
comprised only of static and historical factors, such as age and criminal history. Their limitations included a lack of a theoretical framework, and consisting mainly of static unchanging risk factors. This was, therefore, unreflective of the complexity of recidivism or treatment needs. The third generation included both static and dynamic risk factors that are changeable (for instance, employment and treatment) and over time, for intervention purposes were based on theoretical and empirical associations with criminal behavior. 5 The fourth generation included riskneeds assessment and responsivity factors, such as self-esteem and psychological disorders, to improve response outcomes to intervention and integrated the assessment with a case management plan. ${ }^{6}$ Table 1 summarizes the four generations of risk assessments:

Table 1: Generations of risk assessments

\begin{tabular}{ll}
\hline First generation & $\begin{array}{l}\text { Professionals making clinical judgment on the offender's risk to the } \\
\text { community and treatment needs. }\end{array}$ \\
\hline $\begin{array}{l}\text { Second } \\
\text { generation }\end{array}$ & Utilized only of static/historical factors. \\
\hline Third generation & Included both static and dynamic risk factors \\
\hline $\begin{array}{l}\text { Fourth } \\
\text { generation }\end{array}$ & Included risk-needs assessment and responsively factors. \\
\hline
\end{tabular}

Source: Authors.

Thus, almost 25 years ago, it was recognized that third generation actuarial risk and needs measures are significantly more accurate in predicting recidivism over the first and second generation of risk measures which relied on "clinical intuition and professional judgment.7 This is due to the actuarial approach to predicting future violent behaviors, which has demonstrated a measurable improvement over clinical judgment from 40 to 53 percent, and can be accurate at predicting general recidivism in approximately in 60 to 80 percent of the time. ${ }^{8}$

There are several problems associated with using actuarial tools designed for predicting violent offender's recidivism or relying on professional judgments when assessing devoted, ideological Muslim extremists and terrorists. First, the assessment tools commonly used with violent offenders are not suitable for use to assess extremist/terrorist offenders. Several lines of evidence support this argument: 
- These tools were not standardized for use with terrorist offenders; scales designed to measure extremism and terrorism are more appropriate to focus on issues related to beliefs, thinking, feelings, attitudes, attributions, ideologies and environmental pressures that are held by the person being assessed, such as whether they condone extremism. ${ }^{9}$ However, the majority of the items or subscales in the risk assessment scales commonly used with violent offenders are not related to extreme Muslim extremism and terrorism.

- None of the studies providing face, construct, concurrent and predictive validities for violent criminals' rests on violent Muslim extremist data.

- The assignment of different security levels and housing of offenders based on these scales would not be applicable to extreme Muslim terrorist offenders as the security concerns involved with terrorist offenders are different from those for the regular criminal population. The most recommended strategies for high scoring violent criminals target risk factors irrelevant to extremist Muslim terrorists.

Secondly, Dernevik et al. argue that most mental health professionals do not have any specific expertise in completing assessments on extremists and terrorists. ${ }^{10}$ This is similar to the argument that was raised approximately four decades ago which claimed that there is no evidence that clinicians can reliably and accurately predict violent criminal behavior. ${ }^{11}$

The similarity of this argument becomes more apparent when one examines the reasons raised against having clinicians completing assessments to predict violent criminal behavior. Most of these argue against clinicians conducting Muslim extremist risk assessments. These reasons were due to the many obstacles that assessors faced. ${ }^{12}$ Among these obstacles are the base rate problem, the lack of a precise definition of violence and dangerousness, and the tendency to over-predict violent behavior as the practice of prediction in medicine. ${ }^{13}$ Further, some clinicians make cautious predictions to avoid possible negative consequences including consideration of the assessor's prior expectations, beliefs, and countertransference which may result in clinician's biases and subsequently affect their decisions. ${ }^{14}$ Other obstacles include failing to incorporate situational variables. ${ }^{15}$ For instance, the lack of psychological 
and psychiatric classification to classify violent prone individuals using a limited number of factors or even one factor in reaching clinical decisions. ${ }^{16}$ Furthermore, the lack of precise training is another situational factor because the majority of clinicians who are usually involved in the prediction of criminal or violent behavior are not precisely trained for such a task. ${ }^{17}$ The existing knowledge of the psychological make-up of Muslim extremists and terrorists is scant in important areas, such as their belief systems, cognitions, ideology, organization, decision-making processes, personality dynamics and pathology, and motivations. ${ }^{18}$ There are few clinicians who have an in-depth understanding of the religious, cultural, psychological, historical, political, linguistic, and social backgrounds of the populations from which many of the Muslim extremists' ideologies originate.

For the above noted reasons, the ATRS, formally known as BDS, was developed to assist clinicians in completing risk assessments on Muslims who are motivated by extreme Muslim ideologies. ${ }^{19}$ So far, nine research projects have been completed on the ATRS, which included 1769 participants from Australia, Canada, Egypt, India, Iran, Iraq, Nigeria, Pakistan, Spain, and South Africa that demonstrated the reliability and validity of the ATRS. ${ }^{20}$ Overall, results from the previous research projects indicate that the ATRS is an instrument that can quantitatively measure Muslim extremists' ideologies prevalent in high-risk areas of the world as reported in the literature.

The goals of the current research are to: Further investigate the reliability and validity of ATRS for measuring Middle Eastern Muslim extremists' ideologies; investigate the prevalence of Middle Eastern Muslim extremist ideologies in different parts of the world; and investigate the differences between the responses of different religious groups.

\section{Method}

\section{Participants}

This study involved 1769 participants from several countries including South Africa, Canada, Egypt, Australia, India, Nigeria, Spain, Pakistan, Iran, and Iraq. We recruited a convenience sample for this study. Table 2 summarizes the participants' demographic characteristics 
.Table 2: Demographic Characteristics of Participants

\begin{tabular}{|c|c|c|c|c|c|c|c|c|c|c|c|c|c|c|c|c|c|c|c|c|}
\hline \multirow[t]{2}{*}{$\begin{array}{l}\text { Demograph } \\
\text { ics }\end{array}$} & \multicolumn{2}{|c|}{$\begin{array}{c}\text { South } \\
\text { Africa } \\
(\mathrm{N}=165)\end{array}$} & \multicolumn{2}{|c|}{$\begin{array}{c}\text { Canada } \\
(\mathrm{N}=328)\end{array}$} & \multicolumn{2}{|c|}{$\begin{array}{c}\text { Egypt } \\
(\mathrm{N}=104)\end{array}$} & \multicolumn{2}{|c|}{$\begin{array}{c}\text { Australia } \\
(\mathrm{N}=33)\end{array}$} & \multicolumn{2}{|c|}{$\begin{array}{c}\text { India } \\
(\mathrm{N}=126)\end{array}$} & \multicolumn{2}{|c|}{$\begin{array}{l}\text { Nigeria } \\
(\mathrm{N}=99)\end{array}$} & \multicolumn{2}{|c|}{$\begin{array}{c}\text { Spain } \\
(\mathrm{N}=220)\end{array}$} & \multicolumn{2}{|c|}{$\begin{array}{l}\text { Pakistan } \\
(\mathrm{N}=130)\end{array}$} & \multicolumn{2}{|c|}{$\begin{array}{c}\text { Iran } \\
(\mathrm{N}=388)\end{array}$} & \multicolumn{2}{|c|}{$\begin{array}{c}\text { Iraq } \\
(\mathrm{N}=176)\end{array}$} \\
\hline & $\mathrm{N}$ & $\%$ & $\mathrm{~N}$ & $\%$ & $\mathrm{~N}$ & $\%$ & $\mathrm{~N}$ & $\%$ & $\mathrm{~N}$ & $\%$ & $\mathrm{~N}$ & $\%$ & $\mathrm{~N}$ & $\%$ & $\mathrm{~N}$ & $\%$ & $\mathrm{~N}$ & $\%$ & $\mathrm{~N}$ & $\%$ \\
\hline \multicolumn{21}{|l|}{$\underline{\operatorname{Sex}}$} \\
\hline Male & 35 & 21.3 & 197 & 61.6 & 53 & 51.0 & 11 & $33 \cdot 3$ & 57 & 45.2 & 46 & 46.5 & 86 & 39.1 & 70 & 53.9 & 226 & 58.3 & 99 & $\begin{array}{c}56 . \\
3\end{array}$ \\
\hline Female & 129 & 78.7 & 123 & 38.4 & 51 & 49.0 & 22 & 66.7 & 69 & 54.8 & 53 & $53 \cdot 5$ & $\begin{array}{c}13 \\
4\end{array}$ & 61 & 60 & 46.2 & 162 & 41.8 & 77 & $\begin{array}{c}43 . \\
8\end{array}$ \\
\hline \multicolumn{21}{|l|}{$\underline{\text { Religions }}$} \\
\hline Atheists & 39 & 23.6 & 104 & 32.2 & - & - & 15 & 45.4 & - & - & - & - & 69 & 31.4 & - & - & 41 & 10.6 & 14 & 8 \\
\hline Christ & 103 & 62.4 & 190 & 58.8 & 15 & 14.4 & 16 & 48.5 & 20 & 15.9 & 51 & 51.5 & 113 & 51.4 & 15 & 11.6 & 41 & 10.6 & 31 & 17.6 \\
\hline Muslim & 13 & 7.9 & 27 & 8.4 & 89 & 85.6 & - & - & 34 & 27 & 48 & $\begin{array}{c}48 . \\
5\end{array}$ & 37 & 16.8 & 114 & 88.4 & 138 & 35.6 & $\begin{array}{c}13 \\
1 \\
\end{array}$ & 74.4 \\
\hline Jews & 10 & 6.1 & 2 & 0.6 & - & - & 2 & 6.1 & - & - & - & - & 1 & 0.5 & - & - & 22 & $5 \cdot 7$ & - & - \\
\hline $\begin{array}{l}\text { Other } \\
\text { Religions } \\
\end{array}$ & - & - & - & - & - & - & - & - & 72 & 57.1 & - & - & - & - & - & - & 146 & 37.6 & - & - \\
\hline \multicolumn{21}{|l|}{$\begin{array}{l}\text { Marital } \\
\text { Status }\end{array}$} \\
\hline Single & 103 & 62.4 & 114 & 36.5 & 103 & 99 & 16 & 48.5 & - & - & 65 & 65.6 & $\begin{array}{c}18 \\
3 \\
\end{array}$ & 83.6 & 20 & $15 \cdot 5$ & 139 & 36.5 & 73 & 41.5 \\
\hline Married & 57 & 34.5 & 181 & 58 & 1 & 0.1 & 15 & $45 \cdot 4$ & - & - & 34 & $\begin{array}{c}34 \\
3 \\
\end{array}$ & 34 & $15 \cdot 5$ & 109 & 84.5 & 240 & 63 & 98 & $55 \cdot 7$ \\
\hline Divorce & 5 & 3 & 16 & 5.1 & - & - & 2 & 6 & - & - & - & - & 2 & 1 & - & - & 2 & 0.5 & 5 & 2.8 \\
\hline \multicolumn{21}{|l|}{$\underline{\text { Education }}$} \\
\hline Secondary & - & - & 78 & 24.9 & - & - & 7 & 21.2 & - & - & 5 & $\begin{array}{c}5.0 \\
5\end{array}$ & 5 & 16.2 & 19 & 14.7 & 31 & 8.1 & 49 & $\begin{array}{c}28 . \\
8\end{array}$ \\
\hline College & 124 & 75.2 & 105 & $33 \cdot 5$ & - & - & 1 & 3 & - & - & 18 & 18.2 & 35 & 50 & 85 & 65.9 & 103 & 26.9 & 53 & 31.2 \\
\hline University & 31 & 18.8 & 73 & 23.3 & 103 & 99 & 11 & $33 \cdot 3$ & - & - & 76 & 76.8 & $\begin{array}{c}10 \\
8 \\
\end{array}$ & 31 & 25 & 19.4 & 172 & 44.9 & 68 & 40 \\
\hline Graduate & 10 & 6.1 & 57 & 18.2 & 1 & 0.1 & 14 & 42.4 & - & - & - & - & 67 & 0.5 & - & - & 77 & 20.1 & - & - \\
\hline
\end{tabular}




\begin{tabular}{|c|c|c|c|c|c|c|c|c|c|c|c|c|c|c|c|c|c|c|c|c|}
\hline \multicolumn{21}{|l|}{ Occupation } \\
\hline P. officers & 11 & 6.7 & 21 & 6.6 & - & - & 1 & 3.2 & - & - & - & - & 2 & 1 & - & - & - & - & - & - \\
\hline Student & 71 & 43 & 3 & 1 & 103 & 99 & 5 & 16.1 & - & - & 55 & $55 \cdot 5$ & $\begin{array}{c}14 \\
6\end{array}$ & 67.6 & 8 & 6.2 & 39 & 10.1 & - & - \\
\hline $\begin{array}{l}\text { Social } \\
\text { Work }\end{array}$ & 13 & 7.88 & 105 & 32.9 & - & - & 3 & 9.6 & - & - & 18 & 18.2 & 3 & 1.4 & 1 & 0.8 & 27 & 7 & - & - \\
\hline $\begin{array}{l}\text { Administr } \\
\text { ative }\end{array}$ & 29 & 17.6 & - & - & - & - & 3 & 9.7 & - & - & - & - & 10 & 4.6 & 4 & 3.1 & 64 & 16.6 & - & - \\
\hline Teacher & 26 & 15.8 & - & - & - & - & 3 & 9.6 & - & - & 2 & 2 & 46 & 21.3 & 4 & 3.1 & 78 & 20.2 & - & - \\
\hline Pro. & 15 & 9.1 & 101 & 31.7 & 1 & 0.1 & 16 & 51.6 & - & - & 23 & $\begin{array}{c}23 . \\
2\end{array}$ & 3 & 1.39 & 4 & 3.1 & 91 & 23.6 & - & - \\
\hline Prisoners & - & - & 89 & 27.9 & - & - & - & - & - & - & 1 & 1 & 6 & 2.7 & 108 & 83.7 & 86 & 22.3 & - & - \\
\hline
\end{tabular}

Source: Authors.

Notes: $\mathrm{N}=1769$

Notes: P. officers= Parole officers; Pro. = professional; other religions = Hindus, Sikhs, Zoroastrian, Al-e-Haq. 


\section{Measures}

The ATRS consists of six subscales, with each subscale designed to tap into a prominent ideological theme pertinent to Middle Eastern Muslim extremism. The first subscale (4 items) reflects negative attitudes toward Israel. Many extremists promote the Israeli-Palestinian conflict as a central grievance. ${ }^{21}$ The following is an example of this subscale: The solution to the Middle East problems is to eradicate Israel. The second subscale (five items) is political views that measures Muslim extremists' important political views (for example opposing secular laws and governments, and advocating for the implementation of the Sharia [Islamic] law). ${ }^{22}$ An example of this subscale is the laws that are made by man need replacement by God's mandated laws. The third subscale ( 5 items) assesses participants' attitudes toward women. These current, Muslim extremists' attitudes are mainly repressive, were generally foreign to most Middle Eastern countries, and largely absent prior to the 1970 . ${ }^{23}$ The following is an example of this subscale: Women should always have a male companion from her immediate family when they are traveling. The fourth subscale ( 5 items) measures negative attitudes towards western culture. Muslim extremists have been vocal in their rejection of Western culture. ${ }^{24}$ They claim that Western civilization is corrupt and that the West is trying to undermine their religion. ${ }^{25}$ Extremists generally emphasize the prevalence of negative attitudes in the Muslim countries toward nonMuslim cultures. ${ }^{26}$ An example for this subscale is because of its values, it is hard for believers to integrate in a Western culture. The fifth subscale (6 items), Religiosity, assesses the respondents' commitment to their religion. Extremists use religion to advocate for their cause and to recruit new pools of extremists. ${ }^{27}$ Some questions in this subscale tap into extreme religious views that are common in the Middle East. An example of this subscale is our loyalty should be more to our religion than to the country flags or citizenship. The sixth subscale (8 items), Condoning Fighting, measures views that condone fighting and promotes acts of violence as a means for the revival of religion with the goal of destroying infidels (for example, atheists and nonbelievers in Islam) and achieving one world under the Islamic religion. ${ }^{28}$ An example of this subscale is I support fighting against the nonbelievers of God. A final, seventh, subscale is a validity scale that indicates whether participants misunderstood the items, answered carelessly, or deliberately attempted to conceal their true answers. Items included in this subscale are additional to the 33 items of 
the ATRS. The total score consists of the answers to the items included in the first six subscales (we did not include validity subscale items in the total scale score).

In previous publications, the authors described in detail four stages of ATRS developments. ${ }^{29}$ First, we developed a pool of 100 items to measure attitudes, beliefs, behaviors, and feelings of respondents; this pool was based on the current literature on Middle Eastern extremism and experience with Middle Eastern culture. In the second stage, the writers eliminated several items based in consultation with others. These items were either redundant or unclear. This process reduces and modified a number of items. In the third stage, a content validity study, the authors provided others with the definition of each subscale and the ATRS items. We asked them to read each item and locate it within the most appropriate subscale in their judgment. Several items eliminated. In the fourth stage, we administered the ATRS scale to participants of different religious faiths and then calculated item-subscale correlations and response frequencies for each religious group. The authors dropped items that did not have a strong correlation with their respective subscales $(\mathrm{r}<.30, \mathrm{p}>$.001.) This produced a 33-item scale with six content subscales, a total scale score, and a validity scale. We scored Items on a 4-point Likert scales ranging from 1 (strongly disagree) to 4 (strongly agree). Higher scores indicate more extreme beliefs.

\section{Procedure}

Research conducted to investigate the reliability and validity of the ATRS started in 2010 and it is still going. For this present paper the data collected from the previously conducted research from 10 countries was compiled. The administration of the ATRS was identical for each research project. Participants were advised that the purpose of the study was to validate a scale about diversity of religious beliefs among participants of differing religious backgrounds. They were assured anonymity of their responses and were advised to not identify themselves in any form. Participants were free to decline to participate in the study and were not rewarded or compensated for their participation. Approximately 6 to 10 percent of those who were asked refused to participate. There was no indication that the people who refused to participate significantly differed from those who agreed to go ahead with this research. While some 
completed the ATRS in a classroom setting, others completed the scale in offices or areas that provided a quiet atmosphere. Respondents placed their completed ATRSs in an envelope that contained previously completed questionnaires. The ATRS was translated to the language of the participants who were not competent in understanding the English language.

\section{Results}

A t-test was conducted to compare the ATRS among Muslim, Atheist, Jews, Christian and other religions from different parts of the world. Tables 3, 4, 5 and 6 show the results. Table 3 displays that the range of Coefficient Alphas (CA) for the ATRS subscales was .87 to .89. All items correlated significantly with their respective subscales. The correlations between ATRS subscale scores and the total score ranged from .62 to .80, and there were no noticeable differences between the upper and lower limits of the confidence intervals.

Table 3: Psychometric Properties of ATRS

\begin{tabular}{lllllll}
\hline ATRS Subscales & $\begin{array}{l}\text { Sample } \\
\text { Means }\end{array}$ & $\begin{array}{l}\text { Sample } \\
\text { SDs }\end{array}$ & $\begin{array}{l}\text { Coefficient } \\
\text { Alpha }\end{array}$ & $\begin{array}{l}\text { Ranges of } \\
\text { Item-to-Subscale } \\
\text { Correlations }\end{array}$ & $\begin{array}{l}\text { Total subscale } \\
\text { correlations and } \\
\text { Confidence Intervals }\end{array}$ \\
\hline & & & & & r & $(95 \% \mathrm{Cl})$ \\
\hline Attitude towards Israel & 0.93 & 1.26 & .89 & $.70-.79^{*}$ & 0.62 & $(0.865-0.868)$ \\
\hline Politics views & 1.99 & 1.83 & .87 & $.69-.80^{*}$ & 0.80 & $(1.420-1.423)$ \\
\hline Attitudes toward women & 1.21 & 1.35 & .89 & $.22-.52^{*}$ & 0.66 & $(0.948-0.951)$ \\
\hline $\begin{array}{l}\text { Attitude towards } \\
\text { western culture }\end{array}$ & 1.85 & 1.63 & .88 & $.30-.40^{*}$ & 0.69 & $(1.044-1.046)$ \\
\hline Religiosity & 2.76 & 2.38 & .87 & $.69-.80^{*}$ & 0.79 & $(1.421-1.423$ \\
\hline Condoning fighting & 2.68 & 2.26 & .87 & $.58-.80^{*}$ & 0.80 & $(1.471-1.473)$ \\
\hline Total ATRS & 11.44 & 8.93 & & & & \\
\hline
\end{tabular}

Source: Author

Notes: ${ }^{*} \mathrm{p}<.0001$.

Table 4 displays the correlation coefficients among the ATRS scale and subscales participants of different religious backgrounds. The results indicate that all subscales of the ATRS and total ATRS correlations ranged from .48 to .89 ; they were all significant at the $\mathrm{p}<.001$ level. 
Table 4: Correlations among ATRS Scale and Subscales

\begin{tabular}{|c|c|c|c|c|c|c|}
\hline & Israel & $\begin{array}{c}\text { Politics } \\
\text { views }\end{array}$ & women & $\begin{array}{c}\text { western } \\
\text { culture }\end{array}$ & Religiosity fighting & $\begin{array}{c}\text { Total } \\
\text { ATRS }\end{array}$ \\
\hline Israel & - & & & & & \\
\hline Politics views & $.55^{* * *}$ & - & & & & \\
\hline Women & $.48^{* *}$ & $.57^{* *}$ & - & & & \\
\hline western culture & $.56^{* * *}$ & $.58^{* * *}$ & $.54^{* * *}$ & - & & \\
\hline Religiosity & $.50^{* *}$ & $.75^{* *}$ & $.59^{* * *}$ & $.61^{* *}$ & - & \\
\hline Fighting & $.52^{* * *}$ & $.83^{* *}$ & $.57^{* *}$ & $.57^{* * *}$ & $.77^{* *}$ & \\
\hline Total ATRS & $.69^{* * *}$ & $.88^{* * *}$ & $.74^{* *}$ & $.77^{* * *}$ & $.89^{* * *}$ & - \\
\hline
\end{tabular}

Source: Authors.

Notes: ${ }^{* *} \mathrm{p}<.001$.

Table 5 shows the results of the t-test comparisons between the scores of Muslims with Atheists, Jews, Christians and other religions on the Assessment and Treatment of Radicalization Scale (ATRS). The first column includes the means and Standard Deviations $(S D)$ for the Muslim participants. To avoid redundancy, the authors did not repeat this information for the comparisons between Muslims and Christians, Muslims and Jews, and Muslims and other religions. We report T-test results for the comparisons in columns 3, 5, 7 and 9. All comparisons were significant at $P<.0001$ with Muslim participants always scoring significantly higher than Atheists, Jews, Christians, and other religious groups on all the ATRS scales. 
Table 5: Comparisons between Muslims with Atheists, Jews, Christian and other religions

\begin{tabular}{|c|c|c|c|c|c|c|c|c|c|}
\hline & $\begin{array}{l}\text { Muslims } \\
\text { M (SD) }\end{array}$ & $\mathrm{M}(\mathrm{SD})$ & t-test & $\begin{array}{l}\text { Muslims } \\
\text { vs. } \\
\text { Christian } \\
\text { s } \\
\text { M (SD) }\end{array}$ & t-test & $\begin{array}{l}\text { Muslims } \\
\text { vs. Jews } \\
\text { M (SD) }\end{array}$ & t-test & $\begin{array}{l}\text { Muslims } \\
\text { vs. } \\
\text { Other } \\
\text { Religion } \\
\text { s } \\
\text { M (SD) }\end{array}$ & t-test \\
\hline $\begin{array}{l}\text { Attitude } \\
\text { towards } \\
\text { Israel }\end{array}$ & $\begin{array}{c}1.58 \\
(1.45)\end{array}$ & $\begin{array}{c}0.31 \\
(0.78)\end{array}$ & $13.74^{*}$ & $\begin{array}{l}0.62 \\
(1.03)\end{array}$ & $13.25^{*}$ & $\begin{array}{c}0.29 \\
(0.66)\end{array}$ & $5 \cdot 36^{*}$ & $\begin{array}{c}0.85 \\
(1.00)\end{array}$ & $6.93^{*}$ \\
\hline Politics views & $\begin{array}{c}3.18 \\
(1.62)\end{array}$ & $\begin{array}{c}0.44 \\
(0.94)\end{array}$ & $26.42^{*}$ & $\begin{array}{l}1.50 \\
(1.68)\end{array}$ & $17.84^{*}$ & $\begin{array}{c}1.57 \\
(1.63)\end{array}$ & $5.88^{*}$ & $\begin{array}{c}2.1 \\
(1.48)\end{array}$ & $8.97^{*}$ \\
\hline $\begin{array}{l}\text { Attitudes } \\
\text { toward } \\
\text { women }\end{array}$ & $\begin{array}{c}1.97 \\
(1.36)\end{array}$ & $\begin{array}{c}0.40 \\
(0.78)\end{array}$ & $17.96^{*}$ & $\begin{array}{l}0.734 \\
(1.08)\end{array}$ & $17.47^{*}$ & $\begin{array}{c}0.81 \\
(1.22)\end{array}$ & $5.04^{*}$ & $\begin{array}{c}1.49 \\
(1.42)\end{array}$ & $4.44^{*}$ \\
\hline $\begin{array}{l}\text { Attitude } \\
\text { towards } \\
\text { western } \\
\text { culture }\end{array}$ & $\begin{array}{c}2.65 \\
(1.66)\end{array}$ & $\begin{array}{c}1.04 \\
(1.21)\end{array}$ & $14.76^{*}$ & $\begin{array}{l}1.35 \\
(1.37)\end{array}$ & $15.11^{*}$ & $\begin{array}{c}1.51 \\
(1.33)\end{array}$ & $4.13^{*}$ & $\begin{array}{c}2.06 \\
(1.84)\end{array}$ & $4.57^{*}$ \\
\hline Religiosity & $\begin{array}{c}4.18 \\
(1.89) \\
\end{array}$ & $\begin{array}{c}0.59 \\
(1.23) \\
\end{array}$ & $29.21^{*}$ & $\begin{array}{l}2.176 \\
(2.055) \\
\end{array}$ & $17.77^{*}$ & $\begin{array}{c}1.97 \\
(1.59) \\
\end{array}$ & $6.95^{*}$ & $\begin{array}{c}2.61 \\
(2.04) \\
\end{array}$ & $10.37^{*}$ \\
\hline $\begin{array}{l}\text { Condoning } \\
\text { fighting }\end{array}$ & $\begin{array}{c}4.14 \\
(1.96)\end{array}$ & $\begin{array}{c}0.88 \\
(1.50)\end{array}$ & $24.87^{*}$ & $\begin{array}{l}1.944 \\
(2.180)\end{array}$ & $18.54^{*}$ & $\begin{array}{c}2.97 \\
(2.28)\end{array}$ & $3.48^{*}$ & $\begin{array}{c}3.454 \\
(2.380 \\
)\end{array}$ & $4.20^{*}$ \\
\hline Total ATRS & $\begin{array}{l}17.71 \\
(7.77)\end{array}$ & $\begin{array}{c}3.67 \\
(4.83)\end{array}$ & $28.02^{*}$ & $(7.43)$ & $21.59^{*}$ & $\begin{array}{c}9.14 \\
(6.92)\end{array}$ & $6.56^{*}$ & $\begin{array}{l}12.52 \\
(7.79)\end{array}$ & $8.50^{*}$ \\
\hline
\end{tabular}

Source: Authors.

Notes: ${ }^{*} \mathrm{P}<0.0001$ 
To investigate the trends of the participant responses on the ATRS, participants were grouped into low (total scores of $\leq 5$ ), medium ( $>5$ to $\leq 19$ ), and high (>19) scoring groups, with approximately 33 percent in each group.

Table 6 displays the percentage of each religious groups within Low, Medium, and High ATRS scores. To develop a suggested scheme to be used by professionals involved in the assessment of Middle Eastern Muslim extremists and terrorists, the frequency of the Muslim participants' responses on the ATRS was performed. Results indicated that the highest 10 percentage of the Muslim population scored 26 to 30; the moderates scored 18 to 25 , and the low scored less than 18 .

Table 6: Percentage of Religious Groups on the Low, Medium, and High Scores of the ATRS

\begin{tabular}{lccccc}
\hline ATRS Groups & $\begin{array}{c}\text { Atheists } \\
(282)\end{array}$ & $\begin{array}{c}\text { Christians } \\
(595)\end{array}$ & $\begin{array}{c}\text { Muslims } \\
(631)\end{array}$ & Jews (37) & $\begin{array}{c}\text { Other religions } \\
(218)\end{array}$ \\
\hline $\begin{array}{l}\text { Low } \\
(=<5 ; \mathrm{n}=633)\end{array}$ & $78.72 \%$ & $41.68 \%$ & $9.35 \%$ & $37.84 \%$ & $24.77 \%$ \\
\hline $\begin{array}{l}\text { Medium (>5 to } \\
=<19 ; \mathrm{n}=736)\end{array}$ & $18.79 \%$ & $41.34 \%$ & $41.20 \%$ & $56.76 \%$ & $60.09 \%$ \\
\hline $\begin{array}{l}\text { High } \\
(>19, \mathrm{n}=394)\end{array}$ & $2.48 \%$ & $2.35 \%$ & $49.46 \%$ & $5.41 \%$ & $23.4 \%$ \\
\hline
\end{tabular}

Source: Authors.

\section{Discussion}

Consistent with the previous studies, the results of the present study demonstrated the reliability of the ATRS. There were adequate coefficient alphas for the subscales, strong correlations between the items and their respective subscales, and strong correlations between the total ATRS score and the ATRS Subscale scores. The negligible differences between the upper and lower limits of the confidence intervals reflect the precision of effect size estimates for each of the ATRS subscales.

The validity of the ATRS was demonstrated by the predicted differences among the scores of participants of different religious backgrounds. The prevalence of the extremists' Muslim Middle Eastern ideologies were demonstrated by the fact that participants of the Muslim faith scored significantly higher on the ATRS than participants of other faiths, 
regardless of their country of origin or where they currently live. Another significant finding demonstrated the external validity of the ATRS as an instrument specifically designed to measure Muslim extremes beliefs increasingly seen in Muslim Extremists Middle Eastern ideologies, with 71 percent of the scores of Muslim participants falling into the group designated as high on the ATRS and only 9 percent fell into the Low group. In comparison, the bulk of the scores of Atheists, Christians, Jews, other religions participants fell into the medium and low scoring groups.

The results of this study supported the hypothesis that the prevalence of Middle Eastern Muslim extremists' ideologies as well as the concerns expressed by several Arab and Western writers regarding the prevalence of extreme Muslim Middle-Eastern ideologies around the world. The reported cut-off scores are provided to help assessors in reaching conclusions about the level of risk the client pose to society. Although the ATRS has its own validity scale, it is suggested that other validity measure such as the Balanced Inventory of Desirable Responding helped to determine whether the client is purposely self-enhancing (portraying himself in a positive light) while completing the ATRS. ${ }^{30}$

The ATRS has several advantages. First, because the ATRS is a self-report scale, it ensures maximal objectivity by avoiding possible misinterpretation of participants' responses and it reduces the possibility of assessor biases, which is important in this sensitive area of assessment. Second, the ATRS is more convenient and economical to use than lengthy interviews. Participants simply provide numeric responses indicating agreement or disagreement with the items, with the scale usually taking only a few minutes to complete. Scoring the test is straightforward as the basic interpretation requires minimal professional time. A third advantage of the ATRS is the large proportion of dynamic statements that could be used to measure the effect of any changes over time or after any intervention. A fourth advantage is that individuals' responses can subsequently be used as part of an individualized intervention plan. For example, extreme erroneous thoughts indicated by the endorsement of particular statements could be challenged during treatment. Finally, the ATRS has other practical uses, such as being added to other methods used for screening and identifying applicants with extreme Muslim Middle Eastern views. 
This study adds further evidence to the previously reported research projects about the effectiveness of the ATRS scale as a reliable and valid scale for measuring extremists Muslim ideologies. The ATRS is a contribution to the difficult field of assessing possible or convicted extremists/terrorists. To our knowledge, there is no other known objective scale that is specifically designed to measure extremist Muslim religious ideologies that originate from the Middle East. It is also important to note that the current research involves a large pool of participants who belong to different faiths and from diverse parts of the world. Particularly valuable, is the fact that participants involved in this current research are from Egypt, Iran, Iraq and Pakistan, from which the extreme religious ideologies are promoted and condoned, that these participants were not included in similar previous research, and that these countries include participants from both factions of Islam (for example, Sunni and Shea's). Additional strengths of this study are that most of the co-authors are academics who are well versed in research practices, and some of them are well acquainted with the Middle Eastern religion, cultures, values, language and ideologies.

Similar to the previous studies conducted by the authors, the current study has the following limitations: a) Because of the sensitivity inherent in conducting these types of studies, the preferred randomization process in the selection of participants was not used and collateral data about the participants such as their backgrounds and personalities were not collected; b) There were no other measures available to further assess the concurrent validity of the ATRS; and c). Using the current data for future predictive studies (for example to test whether highly extremist responses will predict terrorist acts) is not possible. Despite the limitations of this research, the results have been consistent and encouraging in that they support the conclusions drawn in many other articles that theoretically discussed the prevalence of extremism. To our knowledge, no previous field research has simultaneously involved participants and researchers from different faiths and different countries such as those involved in this study.

\section{Endnotes}

1 Randy Borum, "Radicalization into Violent Extremism I: A Review of Social Science Theories." Journal of strategic security 4, no. 4 (2011): 7-36. http://dx.doi.org/10.5038/1944-0472.4.4.1; Clark McCauley, and Sophia Moskalenko. "Understanding Political Radicalization: The Two-Pyramid Model." American

Psychologist 72, no. 3 (2017): 205-216. https://doi.org/10.1037/ampooooo62 
2 "List of Islamic Terror Attacks in 2020," The Religion of Peace Website, accessed February 10, 2021, https://thereligionofpeace.com/attacks/europ-attacks.aspx.

3 The Religion of Peace, "List of Islamic Terror Attacks in 2020."

4 Jonathan L Zittrain, Barabas Chelsea, Dinakar Karthik, Ito Joichi, and Virza Madars. "Interventions over Predictions: Reframing the Ethical Debate for Actuarial Risk Assessment." In Proceedings of the 1st Conference on Fairness, Accountability and Transparency, PMLR, no, 81(2018): 62-76; Douglas Mossman, "Assessing Predictions of Violence: Being Accurate About Accuracy," Journal of consulting and clinical psychology 62, no. 4 (1994): 783-792, https: //doi.org/10.1037/0022-006X.62.4.783; Christopher D Webster, Grant T Harris, Marnie E Rice, Catherine Cormier, and Vernon L Quinsey. The Violence Prediction Scheme: Assessing Dangerousness in High-Risk Men. University of Toronto Centre of Criminology (Toronto: University of Toronto, 1994).

5 Zittrain, Chelsea, Karthik, Joichi, and Madars. "Interventions over Predictions: Reframing the Ethical Debate for Actuarial Risk Assessment."

6 James Bonta. "Offender Risk Assessment: Guidelines for Selection and Use." Criminal justice and behavior 29, no. 4 (2002): 355-79, https://doi.org/10.1177/0093854802029004002; Zittrain, Chelsea, Karthik, Joichi and Madars. "Interventions over Predictions: Reframing the Ethical Debate for Actuarial Risk Assessment."

7 Paul Gendreau, Tracy Little, and Claire Goggin. "A Meta-Analysis of the Predictors of Adult Offender Recidivism: What Works!" Criminology 34, no. 4 (1996): 575-6o8. https://doi.org/10.1111/j.1745-9125.1996.tbo1220.x

8 Webster, Harris, Rice, Cormier and Quinsey. The Violence Prediction Scheme: Assessing Dangerousness in High-Risk Men; Don A. Andrews. "Recidivism Is Predictable and Can Be Influenced: Using Risk Assessments to Reduce Recidivism." Paper presented at the Forum on corrections research, 1, no.2 (1989): 11-17.

9 Wagdy Loza, "The Psychology of Extremism and Terrorism: A Middle-Eastern Perspective. Aggression and Violent Behavior 12, no. 2 (2007): 142-43. https://doi.org/10.1016/j.avb.2006.09.001

${ }^{10}$ Dernevik, Mats, Beck, Alison, Grann, Martin et al (2009) The use of psychiatric and psychological evidence in the assessment of terrorist offenders. The Journal of Forensic Psychiatry and Psychology, 20 (4). pp. 508-515. ISSN 1478-9949.

http://dx.doi.org/10.1080/13501760902771217

${ }^{11}$ Association, American Psychiatric. "Clinical Aspects of the Violent Individual." Washington, DC: American Psychiatric Association (1974); American Psychological Association. "Report of the task force on the role of psychology in the criminal justice system." American Psychologist, 33, no 12(1978): 1099-1113.

https://doi.org/10.1037/o003-066X.33.12.1099; Harry L Kozol, Richard J Boucher, and Ralph F Garofalo. "The Diagnosis and Treatment of Dangerousness." Crime \& Delinquency 18, no. 4 (1972): 371-92, https://doi.org/10.1177/001112877201800407; Henry J Steadman, and Gary Keveles. "The Community Adjustment and Criminal Activity of the Baxstrom Patients: 1966-1970." American journal of psychiatry 129, no. 3 (1972): 304-10, https://doi.org/10.1176/ajp.129.3.304; Terence Thornberry, and Joseph E Jacoby. The Criminally Insane: A Community Follow-up of Mentally Ill Offenders. (Chicago: University of Chicago Press, 1979); Vernon L Quinsey, Manfred Pruesse, and Robert Fernley. "A Follow-up of Patients Found Unfit to Stand Trial or Not Guilty Because of Insanity." Canadian Psychiatric Association Journal 20, no. 6 (1975): 461-67.

12 Wagdy Loza. "Predicting Violent and Nonviolent Recidivism of Incarcerated Male Offenders." Aggression and Violent Behavior 8, no. 2 (2003): 175-203, https://doi.org/10.1016/S1359-1789 (01)00055-6

${ }^{13}$ Christopher D Webster, and Robert J Menzies. "The Clinical Prediction of Dangerousness." In Law and Mental Health: International Perspectives, ed. David N. Weisstub (Elsevier: 1987), 158-208; Alexander D Brooks. "Notes on Defining the Dangerousness of the Mentally Iii." Dangerous behavior: A problem in law and mental health 78, no. 563 (1978): 37; Edwin I Megargee. "The Prediction of Violence with 
Psychological Tests." In Current Topics in Clinical and Community Psychology, ed. DN Jackson, and CD Spielberger (New York: Academy Press, 1970), 97-156.

14 Audrey Lee Honig. "Assessing Future Dangerous Behavior: Do the Experts Agree?" (PhD diss., University of Los Angeles, 1982); Loren J Chapman, and Jean P Chapman. "Illusory Correlation as an Obstacle to the Use of Valid Psychodiagnostics' Signs." Journal of abnormal psychology 74, no. 3 (1969): 271, https://doi.org/10.1037/ho027592; Christopher D Webster, Bernard M Dickens, and Susan Addario. "Constructing Dangerousness: Scientific, Legal, and Policy Implications." (Centre of Criminology: University of Toronto, 1985).

15 AE Bottoms. "Selected Issues in the Dangerousness Debate." In Dangerousness: Psychiatric Assessment and Management, ed. John R Hamilton, and Hugh Freeman. (London: Alden Press-Oxford, Royal College of Psychiatrists (1982).

${ }^{16}$ George E Dix. "Determining the Continued Dangerousness of Psychologically Abnormal Sex Offenders." The Journal of Psychiatry \& Law 3, no. 3 (1975): 327-44; Honig. Assessing Future Dangerous Behavior: Do the Experts Agree; Webster, Dickens, and Addario. "Constructing Dangerousness: Scientific, Legal, and Policy Implications."

${ }_{17}$ Brooks. "Notes on Defining the Dangerousness of the Mentally Iii." 37; Park Elliott Dietz. "Hypothetical Criteria for the Prediction of Individual Criminality." In Dangerousness: Probability and prediction, psychiatry and public policy, ed. Webster, C. D., Ben-Aron, M. H. and Hucker, S. J. (New York: Cambridge University Press, 1985, 87-102; Honig. "Assessing Future Dangerous Behavior: Do the Experts Agree?"; Randy K Otto, Kirk Heilbrun, and Thomas Grisso. "Training and Credentialing in Forensic Psychology." Behavioral Sciences \& the Law 8, no. 3 (1990): 217-31; Vernon L Quinsey, and Rudolf Ambtman. "Variables Affecting Psychiatrists' and Teachers' Assessments of the Dangerousness of Mentally Ill Offenders." Journal of Consulting and Clinical Psychology 47, no. 2 (1979): 353; Jennifer L Boothby, and Carl B Clements. "A National Survey of Correctional Psychologists." Criminal Justice and Behavior 27, no. 6 (2000): 716-32.

${ }^{18}$ Rex A. Hudson, "The Sociology and Psychology of Terrorism: Who becomes a Terrorist and Why?" (Washington, DC: Library of Congress, Federal Research Division, 1999); Ariel Merari, "Terrorism as a Strategy of Struggle: Past and Future." In Terrorism and Political Violence, ed. M. Taylor, \& J. Horgan (London: Frank Cass, 2000), 52-65. 19 Wagdy Loza, "The Belief Diversity Scale," (unpublished manuscript, 2007).

${ }^{20}$ Adekunle G. Ahmed, Moses David Audu, Wagdy Loza, and Artur Maximenco, "The Prevalence of Extreme Middle Eastern Ideologies among Some Nigerians," Int'l J. Soc. Sci. Stud. 1 (2013): 161-167, http://dx.doi.org/10.11114/ijsss.v1i2.167.; Wagdy Loza, "The Prevalence of Middle Eastern Extremist Ideologies among Some Canadian Offenders," Journal of interpersonal violence 25, no. 5 (2010): 919-20; Wagdy Loza, "The Prevalence of the Middle Eastern Extreme Ideologies among Some Canadians," Journal of interpersonal violence 26, no. 7 (2011): 1388-400; Wagdy Loza, Youssef Abd-El-Fatah, Johan Prinsloo, Anni Hesselink-Louw, and Katie Seidler, "The Prevalence of Extreme Middle Eastern Ideologies around the World," Journal of interpersonal violence 26, no. 3 (2011): 522-38, https://doi.org/10.1177/o886260510363417; Sukhmeen Kaur Kohli, Anket Sharma, Wagdy Loza, and m Mohanty. "The Use of Assessment and Treatment Scale for Radicalization (ATSR) as a Measure for Assessing Extremist Views in India." The Indian Journal of Social Psychiatry, 29, no.3-4: 108-113; Yusef Karimi, Alexandra Cimbura, and Wagdy Loza. "Reliability and Validity of the Assessment and Treatment of Radicalization Scale (Atrs) on a Sample of Iranians." Journal of Policing, Intelligence and Counter Terrorism (2021): 1-16, https://doi.org/10.1080/18335330.2021.1892165; Yusef Karimi, Alexandra Cimbura, and Wagdy Loza. "Assessing the Prevalence of Middle Eastern Extreme Ideologies among Some Iranians." Journal of Strategic Security 12, no. 3 (2019): 157-69, https://doi.org/10.5038/1944-0472.12.3.1719; José M. Andreu, María E Peña, Wagdy Loza, and Stella Bhawanie. "Assessment extreme ideologies and radicalization-related violence in a community sample in Spain," (submitted). 
${ }^{21}$ Thomas R. Mockaitis, The New Terrorism: Myths and Reality, (California: Greenwood Publishing Group, 2007); Bruce Hoffman, Inside Terrorism, (New York: Columbia University Press, 2006).

${ }^{22}$ Saad Eddin Ibrahim, "Egypt's Islamic Activism in the 1980s", Third World Quarterly 10, no. 2 (1988): 632-57. https://doi.org/10.1080/01436598808420075; Mockaitis, The New Terrorism: Myths and Reality, 42.

23 Kanany-Minesot, GH, "The Saudi-Islamic Invasion to Egypt: A Blind Apostasy from Civilization and a Multi-Violation of Human Rights," The Copts: Christians of Egypt no.22 (1995): 23.

24 Michael J. Mazarr, Unmodern Men in the Modern World: Radical Islam, Terrorism, and the War on Modernity, (Cambridge: Cambridge University Press, 2007); Mockaitis, The New Terrorism: Myths and Reality; Tanveer Ahmed, "The Muslim' marginal Man': Understanding the Psychological and Sociological State of Western Muslims Will Help Integrate Society and Avoid Terrorism," Policy: A Journal of Public Policy and Ideas 21, no. 1 (2005): 35-41.

25 Clark McCauley, "Psychological issues in understanding terrorism and the response to terrorism," in Psychology of terrorism: Coping with the continuing threat, condensed ed. Chris E. Stout (California: Greenwood Publishing Group, 2004): 33-65; Benjamin Orbach, "Usama Bin Ladin and Al-Qa'ida: Origins and Doctrines," Middle East Review of International Affairs 5, no. 4 (2001): 54-68.

${ }^{26}$ David G. Littman, "A Culture of Hate Based on Jihad and Martyrdom: Saudi Arabian and Egyptian Schoolbooks Today," Midstream 51, no. 2 (2005); Irshad Manjii, The trouble with Islam today: A wake-up call for honesty and change, (Toronto: Vintage Canada, 2010); Mockaitis, the New Terrorism: Myths and Reality.

${ }_{27}$ Hafez, Why Muslims Rebel: Repression and Resistance in the Islamic World: 38; Ibrahim, "Egypt's Islamic Activism in the 1980s"; Lotfi, SH, M Ali, and G Kamel, ElMowagha: Tadbeek El-Sharia El-Eslamiah Been El-Haqiqa Wa-Shiaraat El-Fitnah [the Confrontation: Applying the Islamic Sharia between Truth and Rhetoric of Splitting among Muslims], (Cairo, Egypt: Egyptian Organization of Publishing Books, 1993), 9395.; Mazarr, Unmodern Men in the Modern World: Radical Islam, Terrorism, and the War on Modernity; Mockaitis, The New Terrorism: Myths and Reality; Marc Sageman, Understanding Terror Networks. (University of Pennsylvania Press, 2004), 208-9; RL. Schwind, "The London Bombings Hatred in Islam Civil Society and the Umma." Islam review (2005).

${ }^{28}$ Sageman, Understanding Terror Networks, 23; Schwind, The London Bombings Hatred in Islam Civil Society and the Umma.

$293^{30}$ Loza, "The Prevalence of the Middle-Eastern Extreme Ideologies among Some Canadians"; Loza, "The Prevalence of Middle Eastern Extremist Ideologies among Some Canadian Offenders"; Loza, Abd-El-Fatah, Prinsloo, Hesselink-Louw, and Seidler, "The Prevalence of Extreme Middle Eastern Ideologies around the World."

30 Delroy L Paulhus, "Paulhus Deception Scales (Pds): The Balanced Inventory of Desirable Responding-7: User's Manual." Multi-Health Systems North Tanawanda, NY, 1998. 